University for Business and Technology in Kosovo

UBT Knowledge Center

Oct 28th, 9:00 AM - 10:30 AM

\title{
Monuments, Protection and Rehabilitation Zones of Vienna. Genesis and status in legislation and administration
}

Caroline Jaeger-Klein

Technische Universität Wien, jaeger-klein@tuwien.ac.at

Follow this and additional works at: https://knowledgecenter.ubt-uni.net/conference

Part of the Architecture Commons

\section{Recommended Citation}

Jaeger-Klein, Caroline, "Monuments, Protection and Rehabilitation Zones of Vienna. Genesis and status in legislation and administration" (2017). UBT International Conference. 6.

https://knowledgecenter.ubt-uni.net/conference/2017/all-events/6

This Event is brought to you for free and open access by the Publication and Journals at UBT Knowledge Center. It has been accepted for inclusion in UBT International Conference by an authorized administrator of UBT Knowledge Center. For more information, please contact knowledge.center@ubt-uni.net. 


\title{
Monuments, Protection and Rehabilitation Zones of Vienna. Genesis and current status in legislation and administration.
}

\author{
Caroline Jaeger-Klein ${ }^{1}$ \\ ${ }^{1}$ Vienna University of Technology, Department for History of Architecture and \\ Building Archaeology, Karlsplatz 13/251; \\ A-1040 Vienna, Austria \\ jaeger-klein@tuwien.ac.at
}

\begin{abstract}
Austria has a very long tradition in monument protection. Already in 1853 the central commission to research and preserve the built historic monuments started to operate. The current law on monument protection is from the year 1923. Hence the most successful steps to secure the country's built cultural heritage date back to a new provincial legislation, administration and finance system implemented in the early 70ies of the $20^{\text {th }}$ century based on so-called Old City Preservation Acts. By this sensitive approach, the most important historic city centers of Austria like Salzburg, Graz and Vienna could be safeguarded vividly in their traditional characteristics without turning them into dead museum cities. Especially Vienna managed to balance the protection of its extent historic urban environments with parallel ongoing directed urban expansion quite well.

This paper will reflect the genesis of this very successful integrated conservation process for its capital Vienna in the context of the Austrian monument protection tradition and the European Year of Architectural Heritage 1975. Furthermore, the paper will outline the legal, administrative and financial framework. Finally it will describe its different phases of development reacting on and fine-tuning shifting goals to be archived during the course of the times.
\end{abstract}

Keywords: Architectural Heritage, Monument Protection, Integrated Conservation, Old City Preservation Acts, Special Protection Zones, Urban Renewal, Rehabilitation, Revitalization

\section{Introduction}

"In the past few decades, many things have changed in Vienna; in particular, the last five years saw a dynamic development as the geopolitical situation changed. In spite of this, Vienna was able to preserve its identity, cultural uniqueness and typical features. However, no city can remain at a standstill; Vienna is not an open-air museum, nor should it become one. What is significant about its past should be preserved; at the same time, new valuable additions to the urban context must be made. - The expansion of the protection zones ... in order to protect architectural ensembles, the designation of residential zones to support existing uses, the fight against speculation with inhabited properties that deserve preservation - these were and are successful strategies to protect valuable building stock. This stock dates from various eras of history and is part of Vienna's identity. '”[1] 
With this very clear political statement Hannes Swoboda, at that time councillor for Urban Development, Planning and External Relations of the City of Vienna, opened in 1995 an exhibition on the development of a specific concept of urban preservation and gentle urban renewal, which the City of Vienna had started in 1972 by signing, implementing and promoting its Old City Preservation Act. Vienna was not the first Austrian town to set action in this direction. Salzburg already in 1967 devoted itself to an Old City Preservation Act. Besides Salzburg, also Rust and Krems already acted as declared pilot projects (realisation exemplaire) for urban renewal under the umbrella of the European Council. In 1963, the European Council had installed an advisory commission On Ancient Buildings and Historical or Artistic Sites, which was led by the Austrian delegate Ludwig Weiß as Rapporteur of the Cultural and Scientific Committee. Through this overall European action and effort, which culminated in the European Year of Architectural Heritage 1975, the focus within monument protection could be shifted from classical monument protection to the strengthening of architectural ensembles (neighborhoods) [2]. These historic ensembles represent the common cultural heritage of Europe in a distinguish way.

This shift not by incident was strongly related to Austria. The country had already developed long before - still under the rule of the Habsburg Empire and for its then extent territories with a stunning cultural heritage - a precise and encompassing theory for monument protection. The Austrian art historian Alois Riegl, born 1958 in Linz and member of the 1850 installed $k . k$. Central-Kommission (central commission for monument protection within the territories of the Habsburg Empire), published in 1903 his book Der Moderne Denkmalkultus. Sein Wesen und seine Entstehung (The Modern Cult of Monuments, It's character and origin), which clearly declared itself as "preface for the draft of a monuments act", so to speak as first legal framework. In there, Riegl defined a catalogues of objective values, which make a monument preservable. Under his successor Max Dvořák, an Austrian-Bohemian art historian (1874-1921), furthermore a strong development from the preservation of single monuments towards complete ensembles took place, when Dvořák added the feature "picturesque" as category to Riegl's catalogue of values. He illustrated the theory of Riegl by positive and negative examples and therefore finally designed the basics as well as installed guidelines through the 1918 publication Katechismus der Denkmalpflege (Catechism of monument protection). The most influential follower of Dvořák was Archduke Franz Ferdinand, murdered for national political reasons in Sarajevo in 1914, who started to strengthen the k.k. Central-Kommission as state institution. Additionally he created the Kunsthistorische Institut (Institute on History of Art) for documentation and inventory, which was forced to research systematically on historical monuments and sites and publish periodically the results. The former institute on history of art is nowadays integrated into the $B D A$ - Bundesdenkmalamt (Federal Office for the Preservation and Protection of Monuments), but its legacy and mission is unchanged. 


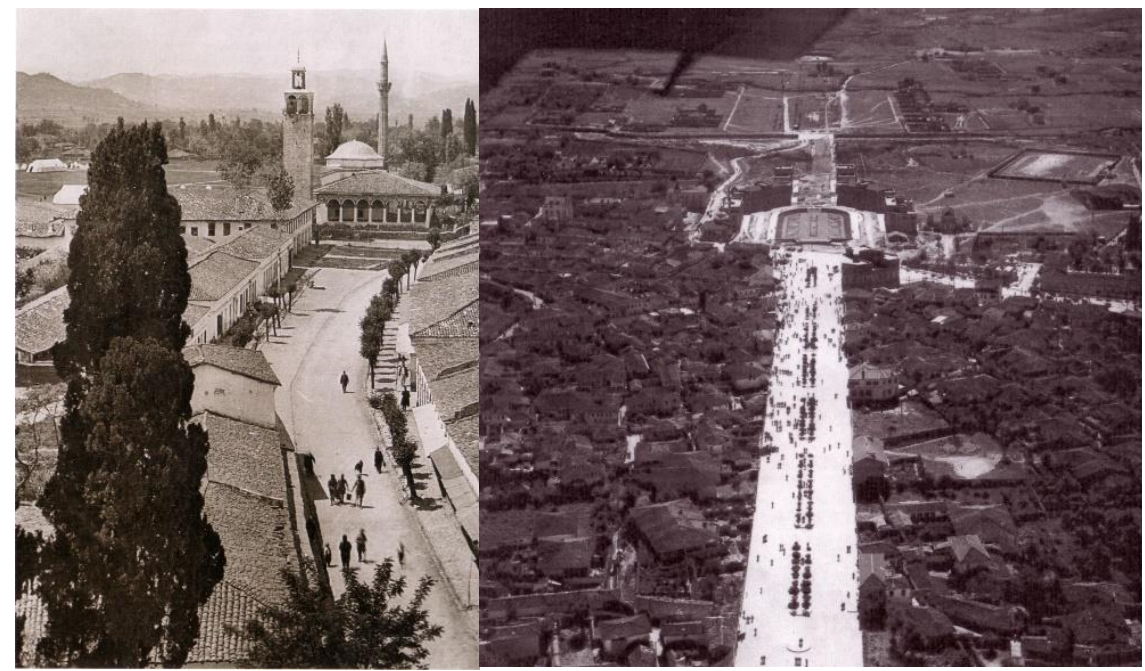

Fig. 1. Tirana, "picturesque" ensemble as positive value example according to Dvořák: Left, the still intact city scape in 1919 and right, the brutal destruction of the traditional city scape through the Italian town planning in the 1940ies (Source: Adolph Stiller, ed., Tirana, Planen, Bauen, Leben, Salzburg-Wien, p.23, 27).

\section{Monuments, Protection and Rehabilitation Zones}

\section{Basics}

Deriving from this genesis, it is obvious that in Austria the preservation of monuments is a public responsibility. The federal monument protection is focusing on authentic and comprehensive preservation of properties important from an artistic, historic or cultural point of view, as the Federal Act on the Protection of Monuments Due to Their Historic, Artistic or Other Cultural Significance - Monument Protection Act-MPA is stating in its very first paragraph: $\S 1$. (1) The provisions of this Federal Act apply to man-made immovable and movable objects (including remains and traces of creative human intervention and artificially constructed or moulded ground formations) of historic, artistic or other cultural significance ("monuments"), if, due to this significance, their preservation is in the public interest. This significance may be due to the objects per se, but may also arise due to their relationship to, or location in relation to, other objects. "Preservation" means protection from destruction, alteration or being dispatched abroad. The preservation activities are enforced by a federal agency, the Federal Office for the Preservation and Protection of monuments (BDA-Bundesdenkmalamt). The pertinent law dates from 1923, but has various amendments from more recent periods [3].

On the contrary and as legacy from the Old City Preservation Acts of the late 60ies and early 70ies of the twenties century, cities like Vienna may define their own areas deemed worthy of preservation as special protection zones in the zoning and land use plan. This is independent and regardless from the federal monument preservation, but has to act on basis of an Old City Preservation Act and has to be organized in organic units. This gives the city authorities control over demolition or changes in characteristic features of its building stock. On this model, Vienna 
since 1972 has created in a gradual process 115 protection zones containing about 12.000 properties, which comprise approximately $8 \%$ of the whole building stock of Vienna. [4].

Based on the results from the early pilot projects mentioned, clearly proofing that a successful implementation of monument protection and the preservation of the urban environment through protection zones can only be safeguarded by effective funding mechanisms, the Vienna Land Provision and Urban Renewal Fund (Wiener Bodenbereitstellungs- und Stadterneuerungsfonds - WBSF) was founded in 1984 to be in charge of implementing the subsidized rehabilitation of residential buildings parallel to the subsidized construction of new housing projects. For new housing projects the WBSF fund purchases the land and participates actively in project development. Originally the balance between funding the rehabilitation of old building substance and supporting new subsidized tenements was equal (50\% each). The housing policy of Vienna tried to keep therewith balance between "inside" and "outside" urban expansion. Its dual strategy is summarized in the key-words of urban densification and urban renewal.

So at the beginning "the construction of 10,000 new subsidized flats annually, must be fulfilled to an extent of $50 \%$ in grown urban structures while the other half is to be constructed in urban development zones. Housing construction activities in development areas are not only capitalintensive because they require additional infrastructure facilities and take up a lot of space; they also take more time for completion. Thus, the concept of >inside< urban expansion and densification is gaining in significance. It is planned to increase the percentage of inner-city housing projects to $60 \%$ in the short to medium term", the official statement of the urban planning authority of Vienna was in 1995 [5].

It might be quite useful to give the financial dimensions of the Vienna Land Provision and Urban Renewal Fund in comparison to the Fund for the Preservation of Vienna's Old City and the subsidies from the Federal Monument Preservation Budget for the year 1984:

Table 1. The financial dimensions of the Vienna Land Provision and Urban Renewal Fund in comparison to the Federal Monument Preservation Budget.

\begin{tabular}{|l|r|r|}
\hline $\begin{array}{l}\text { Vienna Land Provision and Urban Renewal Fund } \\
\text { (Provincial Fund) }\end{array}$ & 21.000 .000 .000 ATS & $93,83 \%$ \\
\hline $\begin{array}{l}\text { Fund for the Preservation of Vienna's Old City } \\
\text { (Provincial Fund) }\end{array}$ & 1.300 .000 .000 ATS & $5,81 \%$ \\
\hline $\begin{array}{l}\text { Federal Monument Preservation Budget } \\
\text { (Federal Fund) }\end{array}$ & 80.000 .000 ATS & $0,36 \%$ \\
\hline
\end{tabular}

But it was clear from the early pilot projects that only with intensive financial and social enhancement actions sustainable preservation and rehabilitation results could be archived. On the other hand, a research started in 1959 clearly proved that the existing building code of Austria as well as the monument protection law was totally sufficient to execute this strategy. The key to efficient ensemble protection lay and still lies in fair and balanced financial support of the average population and its strict evaluation. On example of Krems in 1959, this meant to guarantee loans without depths in maximum of $50 \%$ of the actual costs for rehabilitation of private objects over a time of 10 years [7].

\section{Vienna's Old City Protection Zone Scheme}

When the Vienna Land Provision and Urban Renewal Fund had been founded in 1984, Vienna still had about 136.000 "sub-standard apartments" with toilet or water taps outside the flat. This was the standard equipment of the residential buildings of Gründerzeit ("time of the entrepreneurs"), the boom time of Vienna from 1840 to 1918 , when the city grew from 440.000 
inhabitants to a modern metropolis with 2.38 million people [8]. These older urban residential buildings, all erected by private investment in the $19^{\text {th }}$ century and mostly still in private ownership during the $20^{\text {th }}$ century, but with law restricted flat rents, required above all improvement by way of bathroom and heating installations as well as structural modernization as commitment to more current way of life. But "aggressive" urban renewal models, which in many other big cities had caused tenants' protests, gentrification, segregation and social ghettos, could be avoided by the specifics of the Viennese model of "gentle urban renewal" focusing on the tenant: he/she is not to be displaced by the rehabilitation of the building and must be able to afford the rent even after modernization. Therefore the Province of Vienna granted the generous rehabilitation subsidies. A point system guaranteed that the program would reach those areas that most require rehabilitation. To motivate tenants and building owners, area counselling offices were already established in 1974 in those neighborhoods which required rehabilitation most urgently. These offices were operated by architects or non-profit building societies which worked on behalf of the City of Vienna, but were not permitted to undertake any profit-orientated activity in the respective area [9].
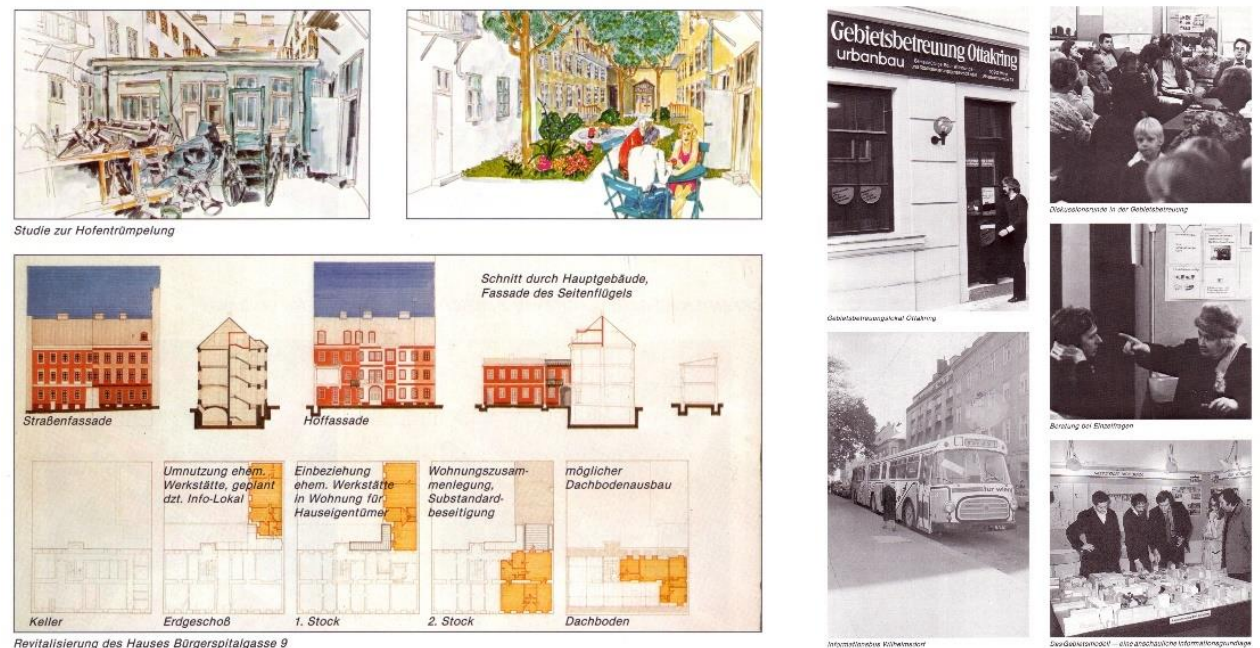

Fig. 2. The Viennese model of gentle urban renewal: Municipal counselling offices run by architects explain the concept to the population of the neighborhood (Source: MA 21/Horst Berger, Gebietserneuerung 1974-1984. Das Wiener Modell, Wien 1984, p.8, 37).

The following rehabilitation methods were implemented and executed between 1972/1984 till 1995 [10]:

1. The comprehensive rehabilitation (Sockelsanierung) was the most important element of the gentle urban renewal. It enabled parallel the preservation and simultaneous improvement (modernization) of inhabited buildings by subsidizing nearly 100\% of the amount of those little improvements (bathroom within flat, upgraded new heating system) for the private tenants or house owners.

2. The block rehabilitation (Blocksanierung) connected the improvements within the houses with improvements of the housing environment such as establishing green zones in inner court-yards, traffic-calming, preserving non-polluting, non-disturbing enterprises and ensure adequate daily supply of goods in the immediate vicinity. The building owners, tenants and enterprises were involved into the process from the very beginning. 
3. In turn, the total rehabilitation (Totalsanierung) concept referred to the complete rehabilitation of a building including its conversation from tenements to owner occupied, fully equipped apartments. The whole process was certainly a Vienna specific reuse issue and did not mean, what nowadays is called adaptive reuse in general.

4. The individual improvement (Einzelverbesserung) concept comprised measures without comprehensive rehabilitation, for example the installation of an elevator (lift) or addition of a heat insulation. Therefore the extent of the subsidy depended heavily on the measures undertaken and the sum invested by the applicant himself/herself.

5. Maintenance work (Erhaltungsarbeiten) included all measures which were taken to preserve the building but not improve it in the sense of renovation of the façade, roof repair etc. Grants were only given, if the flats inside where of the lowest category.

6. Finally, small-scale flat improvements (Kleine Wohnungsverbesserung) of an individual apartment were usually given upon an application by the tenant for installation of a bathroom or water toilet without an overall concept for the whole house.

The key and corner-stone of the whole concept certainly is and was the so-called comprehensive rehabilitation, as it was above all motivated by the strict observance of social needs. Priority was given to preserving existing houses as opposed to the demolition and construction of new buildings. The rights of the tenants were safeguarded and the inhabitants and their wishes taken into account in the rehabilitation concept. The subsidy was granted irrespective of ownership, which avoided changes in ownership structures enforced by subsidized rehabilitation. Now, after the first generation that profited from the program has died out, a modest gentrification process is taking place. Most important under the auspices of a sustainable conservation approach was that the small-scale mix structures could be preserved and the general urbanistic structure of the densely built-up zones were improved. This kind of comprehensive rehabilitation represents a holistic and gradual concept of building rehabilitation which does not disrupt or modify the legal position and situation of the tenants and users of the buildings [11].

\section{Vienna 's New Protection Zone Scheme}

After the first 20 years of successful implementation of the old protection zone scheme, a review after shifted international assessment attitudes caused several changes. The new, up-to-date protection zone scheme focused on a variety of factors like archaeological, natural, topographical, structural, visual and construction elements and multiple levels of evaluation like the historical reference system and use and identity as major features of reference. It established objectives for the differentiation of protected objects, the identification of potential developments in protected zones, the clear identification of elements and the increasing integration of the population. To archive the objectives the following steps were initiated as model for an overall scheme:

1. Identification of city areas based on inspections where protection measures are yet to be defined (large maps).

2. Express inventory in these areas to arrive at a rough delineation of potential new protection zones. The stock-taking includes a survey of the history and typology of buildings and of the city structure.

3. For the areas identified in the course of the express inventor, a basic inventory including the age, height and type of the building as well as the urban structures, the building structure and the monument protection issue was established.

4. The last step was an item-by-item inventory of all properties situated in Protection Zones (and therefore an in number far larger inventory than the one from the Federal Office of Monument Protection), collecting general administrative data, historical data, an architectural and technical description, the state of preservation, an analysis from the point of view of monument preservation as well as required building measures [12]. 
The new method now distinguishes between fully protected structures (Schutzobjekte), essentially protected structures (Schonobjekte) and non-protected structures. All inspection data are computerized in form of an cultural heritage database, implanted into the geoinformation system (GIS) and processed in form of an open-source multi-purpose city map plus database, electronically accessible for everybody under Kulturgut Wien. The cultural (and natural) heritage map and the affiliated database inform the civil society as well as the authorities and scientists about monument protection issues, the building periods, building types, construction and material, other cultural values, their current physical condition and overcome damages like the one from World War II.
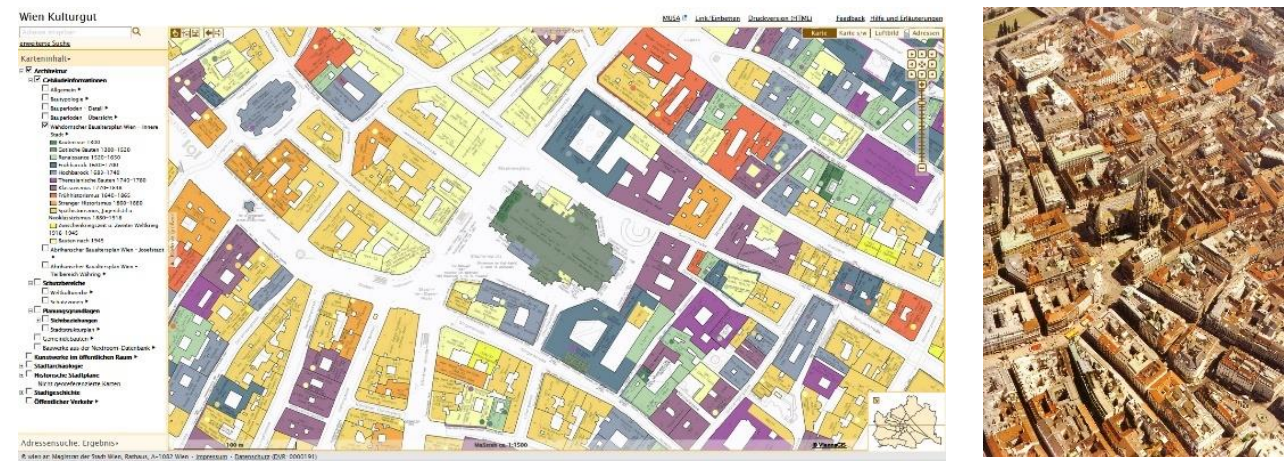

Fig. 3. Kulturgut Wien - interactive public cultural heritage database: The civil society gains open access to manifold information about its cultural heritage - protection status, building type and period, war damage, material and construction and physical condition etc. (Source: www.wien.gv.at/stadtentwicklung/grundlagen/schutzzonen).

\section{Vienna's Discussion on Contemporary Building Projects within its Historic Cultural Heritage}

In 1992 Austria officially ratified the UNESCO World Heritage Convention, 20 years after its origin. In 2001 the Historical City Center of Vienna was inscribed into the UNESCO World Heritage List as $7^{\text {th }}$ Austrian site. It was listed as cultural heritage with an outstanding universal value (OUV) according to criterion ii, iv and vi. The inscription was justified for the following reasons:

Criterion ii: The urban and architectural qualities of the Historic Centre of Vienna bear outstanding witness to a continuing interchange of values throughout the second millennium.

Criterion iv: Three key periods of European cultural and political development - the Middle Ages, the Baroque period and the Gründerzeit - are exceptionally well illustrated by the urban and architectural heritage of the Historic Centre of Vienna.

Criterion vi: Since the $16^{\text {th }}$ century Vienna has been universally acknowledge to be the musical capital of Vienna.

Without the described Protection Zone Schemes of Vienna, the successful inscription into UNESCO's World Heritage would have been totally impossible. Hence, as soon as the inscription process was started, turmoil on contemporary architectural projects started: around the inscription it was height and size of the Wien-Mitte urban development project on the edge of the buffer zone that was criticized heavily inside Austria as well as by ICOMOS, the international experts' advisory body of UNESCO. Also the World Heritage Committee considered the plans for the new structure detrimental to the appearance of the Viennese inner city. Finally the inscription was awarded with the recommendation that the project be evaluated in terms of compatibility 
with the visual integrity of the historical city. The Committee also recommended that special attention be paid to the observation of all changes in the morphology of historical buildings [13].

Based on the concerns expresses by the World Heritage Committee, an evaluation took place to establish the perspectives at which the towers would have a negative effect on the World Heritage site. The city of Vienna created a scientific visibility analysis based on a computerized 3D city model which since then is obligatory for building projects within its cultural heritage. The discussions as well as the visualizations triggered a sensitization process around contemporary architecture within historical ensembles and led to the Viennese Memorandum on the Implementation of Contemporary Architecture in Historic cityscapes in 2005 on international level. In 2011, the $17^{\text {th }}$ ICOMOS General Assembly adopted these first ideas in final The Valetta Principles for the Safeguarding and Management of Historic Cities, Towns and Urban Areas. On national level, the Vienna Municipal Council approved in April 2002 New Guidelines for the Planning and Evaluation of High-Rise Projects. They define exempted zones from high-rise construction which are the following: All established protected zones (Schutzzonen) in accordance with the Vienna Building Code, all established and proposed protected landscape areas in compliance with the Vienna Nature Protection Law, all important visual axes and visual relations and finally all World Heritage sites in Vienna [14].

\section{Concluding Remarks}

For 15 years, the agreement on the zones exempted from high-rise construction was well respected and accepted in Vienna. Despite, at this years' general meeting of the World Heritage Committee in Krakow, the Historic City Center of Vienna was put on the international Red List of Risked Heritage of UNESCO for another high-raised building structure within its World Heritage Core Zone, the so-called Heumarkt project. Under heavy pressure of an aggressive investor in combination with heavy financial problems of the city administration of Vienna, the referred municipal guidelines from 2002 have been changed to favor this particular project. Heavy protests from the properly informed part of the population in accordance with NGO monument protection initiatives, the architects' chamber of Austria and the national and international ICOMOS experts were and are still ongoing. For the moment there is hardly any hope for a sensitive solution of the issue. With this project, the City of Vienna finally has ruined its worldwide reputation as role-model for gentle urban renewal. Still in its preparatory stage, the model in 1993 won the Premio Gubbio. In 1996, the UNCHS (UN-Centre for Human Settlements), awarded the "Viennese model of gentle urban renewal" out of 600 international projects, and in finally in 1998, the UN-ECE (the European Economical Organisation of UN) declared the "Viennese Case Study on Urban Renewal and Housing Modernization" as rolemodel for other cities [15].

\section{References}

1. Urban Planning Vienna (ed.), Vienna. Preservation and Renewal of the Urban Environment. A Report on the Current State of Affairs, Vienna, 1995, Foreword

2. Jaeger-Klein, Caroline, „Die Stadtbauaufnahme-Aktion Österreich und das Europäische Jahr des architektonischen Erbes 1975", 115-125 in: Eine Zukunft für unsere Vergangenheit. Zum 40. Jubiläum des Europäischen Denkmalschutzjahres (1975-2015), M. Falser, W. Lipp (ed.), Berlin, (2015); 115, 120 
3. Federal Act on the Protection of Monuments Due to Their Historic, Artistic or Other Cultural Significance (Monument Protection Act - MPA); Original Version: Federal Gazette Nr. 533/1923 with several amendments from 1978 to 2013. The full-length text is available in an unauthorized, but officially launched English version via the homepage of the Federal Institute on Monument Protection of Austria (bda.gv.at/eng/legal framework)

4. Wehdorn, Manfred, Wien - Vienna. Das historische Zentrum: Weltkulturerbe der UNESCO - The historical Centre: UNESCO World Heritage Site, Wien-New York 2004, 93

5. Urban Planning Vienna (ed.), Vienna. Preservation and Renewal of the Urban Environment. A Report on the Current State of Affairs, Vienna, 1995, 69

6. Urban Planning Vienna (ed.), Vienna. Preservation and Renewal of the Urban Environment. A Report on the Current State of Affairs, Vienna, 1995, 53

7. Jaeger-Klein, Caroline, „Die Stadtbauaufnahme-Aktion Österreich und das Europäische Jahr des architektonischen Erbes 1975", 115-125 in: Eine Zukunft für unsere Vergangenheit. Zum 40. Jubiläum des Europäischen Denkmalschutzjahres (1975-2015), M. Falser, W. Lipp (ed.), Berlin, (2015); 120

8. Bobek, Hans, Lichtenberger, Elisabeth, Wien. Bauliche Gestalt und Entwicklung seit der Mitte des 19. Jahrhunderts, Wien-Köln 1978, p. 31, tab. I

9. Urban Planning Vienna (ed.), Vienna. Preservation and Renewal of the Urban Environment. A Report on the Current State of Affairs, Vienna, 1995, 57

10.Urban Planning Vienna (ed.), Vienna. Preservation and Renewal of the Urban Environment. A Report on the Current State of Affairs, Vienna, 1995, 59

11.Urban Planning Vienna (ed.), Vienna. Preservation and Renewal of the Urban Environment. A Report on the Current State of Affairs, Vienna, 1995, 61-63

12.Kobermaier, Franz, Kreppenhofer, Anna and Matousek, Josef, „Das Neue Schutzzonenmodell für Wien“, in: Schrenk, Manfred (ed.), Computergestützte Raumplanung. Beiträge zum Symposium CORP'98 (ISBN 3-901673-02-4) and Urban Planning Vienna (ed.), Vienna. Preservation and Renewal of the Urban Environment. A Report on the Current State of Affairs, Vienna, 1995, p. 77-83

13. Wehdorn, Manfred, Wien - Vienna. Das historische Zentrum: Weltkulturerbe der UNESCO - The historical Centre: UNESCO World Heritage Site, Wien-New York 2004, p. 24

14. Wehdorn, Manfred, Wien - Vienna. Das historische Zentrum: Weltkulturerbe der UNESCO - The historical Centre: UNESCO World Heritage Site, Wien-New York 2004, p. 106

15. Wehdorn, Manfred / Stadt Wien (ed.), Wien und das Weltkulturerbe. Sondernummer Perspektiven (der aufbau), Wien Dezember 2002, 68. 